\title{
PD-L1 expression correlates with immune response in a Phase I trial of CCL21 gene modified dendritic cell therapy in lung cancer
}

\author{
Jay M Lee*, Edward B Garon, Mi-Heon Lee, Gerald Wang, Dörthe Schaue, Felicita Baratelli, Fereidoun Abtin, \\ Robert Suh, William D Wallace, Gang Zeng, Sherven Sharma, Steven M Dubinett
}

From Society for Immunotherapy of Cancer 29th Annual Meeting

National Harbor, MD, USA. 6-9 November 2014

\section{Background}

Anti-tumor immune response in lung cancer patients may be evoked by intra-tumoral (IT) administration of autologous dendritic cells (DC), transduced with a replication-deficient adenoviral (Ad) vector to express the secondary lymphoid chemokine (SLC/CCL21) gene. Here, we evaluated tumor specific immune response after CCL21 gene-modified DC (Ad-CCL21-DC) administration in the context of tumor PD-L1 expression.

\section{Methods}

Phase I, non-randomized, dose escalating, multi-cohort trial was conducted to enroll patients with Stage IIIB/IV NSCLC. Sixteen patients received 2 vaccinations at a dose of Ad-CCL21-DC (A, B, C, or D; $1 \times 10^{6}, 5 \times 10^{6}, 1 \times 10^{7}$, or $3 \times 10^{7}$ cells/injection) by IT injection (days 0 and 7). Peripheral blood was collected for antigen-specific ELISPOT assays, and CT guided needle biopsies of the primary lung cancer were obtained for PD-L1 expression by real time PCR and evaluation of cellular infiltrates by immunohistochemistry.

\section{Results}

Peripheral blood of 16 subjects was evaluated by ELISPOT assays. Positive response was defined as 2-fold increase in number of spots above background with an absolute number of $>20$ spots $/ 2 \times 10^{5}$ cells (positive responder; PR). A mixed response was defined as a positive response with high IFN- $\gamma$ background expression at day 0 compared to post-vaccine time points (mixed responder; MR). There were $19 \%(3 / 16)$ PR and 19\% (3/16) MR for a total of $38 \%$ $(6 / 16)$ total responders. The average PD-L1 gene copy

University of California, Los Angeles, CA, USA number was 1344 (non-responder; NR) compared to 394 (MR), and 684 (PR) on day 7. Tumor CD8 T cell infiltration was induced in $40 \%(6 / 15$; all subjects), $33 \%(3 / 9$; $\mathrm{NR})$, and $50 \%$ (3/6; MR \& PR).

\section{Conclusion}

Intra-tumoral administration of autologous dendritic cells expressing the SLC/CCL21 gene demonstrated that 1) anti-tumor specific immune responses are elicited and correlate with lower PD-L1 expression, and 2) CD8 $\mathrm{T}$ cell infiltration into the tumor is induced.

Published: 6 November 2014

doi:10.1186/2051-1426-2-S3-O20

Cite this article as: Lee et al.: PD-L1 expression correlates with immune response in a Phase I trial of CCL21 gene modified dendritic cell therapy in lung cancer. Journal for ImmunoTherapy of Cancer 2014 2(Suppl 3):O20.

Submit your next manuscript to BioMed Central and take full advantage of:

- Convenient online submission

- Thorough peer review

- No space constraints or color figure charges

- Immediate publication on acceptance

- Inclusion in PubMed, CAS, Scopus and Google Scholar

- Research which is freely available for redistribution

Submit your manuscript at www.biomedcentral.com/submit C) BioMed Central 